\title{
Application of a dry heat treatment to enhance the functionality of low-heat nonfat dry milk
}

\author{
K. Sanchez Alan, ${ }^{1}$ J. Subbiah, ${ }^{2}$ and K. A. Schmidt ${ }^{1,3 *}$ \\ ${ }^{1}$ Food Science Institute, Kansas State University, Manhattan 66506 \\ ${ }^{2}$ Biological Systems Engineering, and Food Science and Technology Department, University of Nebraska, Lincoln 68583 \\ ${ }^{3}$ Department of Animal Sciences and Industry, Kansas State University, Manhattan 66506
}

\section{ABSTRACT}

Nonfat dry milk is a valuable food and ingredient because it contains proteins, fat, carbohydrates, minerals, and vitamins. When manufactured, this product is classified into high heat (HH) or low heat ( $\mathrm{LH})$ depending on the pre-heat treatment used in pasteurization. Radio frequency dielectric heating, if used alone or as part of a dry heat technology, may induce component interactions in milk powders, which could alter or improve functionality. To pursue this objective, LH was subjected to radio frequency dielectric heating to 80 , 85 , and $90^{\circ} \mathrm{C}$ with a subsequent hold period of 60 or 90 min in an oven, set at the designated temperature, 80, 85 , or $90^{\circ} \mathrm{C}$, assessed for functionality in liquid and gel systems, cooled, and subsequently compared with LH and HH. The functionality assessment included heat stability and foaming, emulsion, and gelling properties. For foaming, LH presented a statistically lower overrun and foam stability compared with all dry-heated LH. The LH dry-heated at $\geq 85^{\circ} \mathrm{C}$ exhibited significantly greater foaming capacity than did the LH. Emulsification properties were not significantly different as a function of dry heating compared with LH. As gels, water-holding capacity was greater and syneresis was significantly less for all gels made with the dry-heated $\mathrm{LH}$ at $<85^{\circ} \mathrm{C}$. Gel firmness and cohesiveness were not affected by dry heating. The heat coagulation time at native $\mathrm{pH}$ was significantly greater for $\mathrm{LH}$ that were dry-heated for 90 min compared with LH. At adjusted $\mathrm{pH}$ (6.4 to 7.2), the heat stability was improved if the LH was dry-heated. The dry-heated LH had significantly less foaming properties, but greater emulsion activity compared with the HH. Overall, the dry heat treatment conditions of this study did not result in acid-induced gels with equivalent properties as gels made with $\mathrm{HH}$. Syneresis was similar for all gels except for those made

Received June 20, 2018.

Accepted October 21, 2018

*Corresponding author: kschmidt@ksu.edu from the dry-heated $\mathrm{LH}$ to $90^{\circ} \mathrm{C}$ and held for $60 \mathrm{~min}$, as this gel had significantly more syneresis than did the gels made from HH. However, the heat stability of dryheated $\mathrm{LH}$ at native, $6.8,7.0$, and $7.2 \mathrm{pH}$ was greater compared with the heat stability of HH. The application of a dry heat treatment enhanced the functional properties of LH, opening the opportunity to develop food products that can use this modified nonfat dry milk such as ice cream, bakery, and meat products.

Key words: radio frequency dielectric heat treatment, nonfat dry milk, functional properties

\section{INTRODUCTION}

The dehydration of milk has been used to facilitate storage and increase appeal when used as an ingredient in foods such as yogurt, baked goods, or sauces. Nonfat dry milk (NDM) is one of the most popular dehydrated milk products in the US market and is manufactured as low heat (LH), medium heat (MH), and high heat (HH; Patel and Patel, 2015). Low heat and HH are predominantly used as ingredients in food as they improve functional properties such as foaming, gelling, emulsification, and heat stability (Sharma et al., 2012; Patel and Patel, 2015).

Milk is a complex system where treatments such as heating or drying affect protein structure, leading to denaturation, aggregation, and insolubility. The extent of these changes depends on the heat conditions applied to milk, the component ratios in the milk, and the moisture content of the milk system. For example, when heating dried milk systems the molecular motions of the components are retarded, thus slowing chemical reactions, in particular protein denaturation and aggregation, compared with heating a rehydrated milk system (Gulzar et al., 2011).

The heating conditions are critical during the manufacture of NDM. The pre-heat treatment applied to the liquid skim milk before spray drying typically controls the degree of whey protein (WP) denaturation, which in turn affects functional properties. Typically, when 
making LH the skim milk undergoes a pre-heat treatment at $70^{\circ} \mathrm{C}$ for $15 \mathrm{~s}$, compared with the skim milk for $\mathrm{HH}$, which is subjected to heat conditions of 90 to $120^{\circ} \mathrm{C}$ for 1 to $5 \mathrm{~min}$ (Kelly et al., 2003). These different process conditions result in different functional properties in the resultant powders. For example, the LH possesses greater solubility and less cooked flavor, whereas the $\mathrm{HH}$ has greater gelation properties, heat stability, water binding, and water absorption (Kelly et al., 2003). Whereas LH is used mainly in yogurts, $\mathrm{HH}$ is preferred in the baking industry (Sharma et al., 2012). Although markets exist for both products, the manufacture of $\mathrm{HH}$ can be a more complicated process as opposed to LH because WP tend to aggregate and agglomerate when denatured in liquid systems (Mulvihill and Donovan, 1987; Singh and Creamer, 1991).

Radio frequency dielectric heating (RFDH) technology is not a new to the food industry, as this technology has been explored for various uses, from a technology to reduce microbial loads in foods to disinfection strategies in nuts and seeds, and from completing the baking process in pre-baked goods to enhanced quality improvements in dried egg products. More specifically, RFDH has been reported to inactivate enzymes in rice bran and wheat germ, thus extending shelf life and improving quality (Ling et al., 2018a,b). In recent years, RFDH has reduced the pathogenic risks in low moisture products, such as NDM and red and black pepper spices, and eliminated pathogens in liquid systems, such as apple cider (Michael et al., 2014; Jeong and Kang, 2014; Hu et al., 2018).

Additionally, RFDH was used to heat NDM to various temperatures, which was then held for various times in a convection oven (preset at the same temperature as the NDM in the RFDH). These RFDH-treated milk powders were reported to have decreased solubility and whey protein nitrogen index (WPNI; Chen et al., 2013). In particular, if these RFDH-treated HH and $\mathrm{LH}$ were subjected to a RFDH treatment of $\geq 80^{\circ} \mathrm{C}$, the WPNI was significantly reduced in LH, suggesting that protein denaturation occurred during the overall dryheating process. As expected, the authors reported that solubility values for the RFDH-treated LH were greater than those of $\mathrm{HH}$, whether the $\mathrm{HH}$ was RFDH-treated or not (Chen et al., 2013). Moreover, a similar RFDHtreatment of LH exhibited improved heat stability at 6.4 to $6.8 \mathrm{pH}$ (Sanchez Alan et al., 2017). The authors attributed the improved stability to the partial WP denaturation that occurs during the overall dry-heating process of $\mathrm{LH}$ at 75 or $80^{\circ} \mathrm{C}$.

Egg white powder (EWP) had been treated in a RFDH unit (Boreddy et al., 2016). The RFDH-treated EWP exhibited improved foaming and gelling properties especially as the treatment temperature and time increased. Their study showed that the RFDH-treated EWP $\left(90^{\circ} \mathrm{C}\right.$ for $\left.24 \mathrm{~h}\right)$ produced maximum foaming capacity that exceeded the traditionally processed EWP $\left(60^{\circ} \mathrm{C}\right.$ for 10 to $\left.14 \mathrm{~d}\right)$. The authors produced and evaluated gels from the different RFDH-treated EWP. They found that gels made from RFDH-treated EWP at lower temperatures $\left(60\right.$ and $\left.70^{\circ} \mathrm{C}\right)$ have significantly less water-holding capacity (WHC) compared with gels made from traditionally processed EWP. Nevertheless, in gels made from RFDH-treated EWP at 80 and $90^{\circ} \mathrm{C}$, the WHC was similar to the gel made from the traditionally processed EWP. Another advantage was the reduced energy consumption if EWP was treated with RFDH; the total processing time decreased from $14 \mathrm{~d}$ to $<1 \mathrm{~d}$ at $90^{\circ} \mathrm{C}$ (Boreddy et al., 2016). In these studies on NDM and EWP, the researchers used the RFDH unit to quickly increase the temperature of the powder (milk or egg white) to the desired temperature, and then transferred the product to a convection oven for a hold period at a consistent temperature.

Considering that markets are feasible for both $\mathrm{HH}$ and $\mathrm{LH}$ as ingredients, and that the manufacture of HH may be more challenging due to denatured WP, an alternative may be to manufacture LH and use the RFDH technology to produce a product that functions more similar to $\mathrm{HH}$, or perhaps to produce a NDM product with unique functionality. As described in previous literature, we hypothesized that a dry heat treatment consisting of RFDH technology to rapidly heat the powder to a specified temperature combined with a hold period in a convection oven (preset at the designated temperature) could improve the functional properties of LH. Thus, the objectives of this study were to improve the functionality of $\mathrm{LH}$, specifically foaming, gelling, emulsion, and heat stability properties using a dry-heating process, and to determine if the dry-heated LH has similar functionality as the HH.

\section{MATERIALS AND METHODS}

\section{Samples}

The HH was obtained from ConAgra Foods Inc. (Menomonie, WI). The LH was obtained from Dairy America Inc. (Fresno, CA).

\section{Compositional Analysis}

The NDM samples were analyzed for composition by proximate analysis. Total protein was determined using the Dumas principle from IDF Standard 185 (IDF, 2002). Fat content was determined by microwave drying followed by nuclear magnetic resonance (SMART Trac Fat and Moisture Analyzer; CEM Corporation, Mat- 
thews, NC) following the method created in this equipment for skim milk (Samarokoon, 2016). Ash content was determined by ignition at $550^{\circ} \mathrm{C}$ in a muffle furnace (AOAC International, 2002). The moisture content was determined by the oven-drying method (AOAC International, 2002). Carbohydrate content was calculated by the difference (AOAC International, 2002).

\section{Dry Heating}

A 6-kW parallel-plate RFDH unit (Monga Strayfield Pvt. Ltd., Pune, India) operating at $27.12 \mathrm{MHz}$ was used to treat the NDM. The dry heating treatment occurred exactly as outlined by Michael et al. (2014), except that the electrode distance (upper electrode to the top surface of the NDM) was $120 \mathrm{~mm}$.

To briefly recap the procedure, $\sim 350 \mathrm{~g}$ of $\mathrm{LH}$ was placed in a circular, high-density polyethylene tray $(0.3$ $\mathrm{cm}$ thick, $19.0 \mathrm{~cm}$ diameter, and $2.7 \mathrm{~cm}$ height; Dynalab Corp., Rochester, NY), leveled with a straightedge, and placed uncovered in the RFDH unit. Four fiber-optic probes (T1, Neoptix Inc., Québec, Canada) were placed in the $\mathrm{LH}$ at the container's edge, about $3 \mathrm{~cm}$ from the container's edge, $3 \mathrm{~cm}$ from the center, and center. The probes were connected to a data logger (Reflex, Neoptix Inc.) to record the heating profile during the RFDH heating process. The LH was heated to 80,85 , or $90^{\circ} \mathrm{C}$ in the unit, and when the center probe reached the target temperature, LH was transferred to a convection oven (preset at the target temperature; Thelco, GCA/Precision Scientific, Schaar Scientific Company, Chicago, IL) and held or 60 or $90 \mathrm{~min}$.

After the hold period, the tray was removed from the oven, $\mathrm{LH}$ cooled at $23^{\circ} \mathrm{C} \pm 1^{\circ} \mathrm{C}$, and $\sim 200 \mathrm{~g}$ of dry-heated LH was removed from the center of the tray and placed into separate, resealable polyethylene bags (0.93-L Ziploc freezer bags, Racine, WI) and stored at $-2 \pm 1^{\circ} \mathrm{C}$ (Equatherm, Lab-Line Instruments Inc., Melrose Park, IL) until assessment.

Based on preliminary research the following temperature and time combinations were studied: RFDH heating to $80 \pm 1^{\circ} \mathrm{C}, 85 \pm 1^{\circ} \mathrm{C}$, and $90 \pm 1^{\circ} \mathrm{C}$ followed by holding in a hot-air oven at 80,85 , or $90^{\circ} \mathrm{C}$, respectively, for 60 and 90 min. For ease of understanding, the dry-heated LH will be designated by numbers using the treatment as temperature/time conditions. For example, 80/60 will represent $\mathrm{LH}$ heated in the RFDH unit to $80^{\circ} \mathrm{C}$ and then held for $60 \mathrm{~min}$ at $80^{\circ} \mathrm{C}$ in a convection oven, whereas sample 80/90 represents LH heated in the RFDH unit to $80^{\circ} \mathrm{C}$ and held for $90 \mathrm{~min}$ at $80^{\circ} \mathrm{C}$ in a convection oven. The same format was applied to the rest of the dry-heated LH: $85 / 60,85 / 90$, $90 / 60$, and $90 / 90$. Because of the nature of the study's objectives, 2 controls were used: HH designated as $\mathrm{HH}$ and non-dry-heated LH designated as LH.

\section{Whey Protein Nitrogen Index}

The WPNI was calculated from the standard references from the American Dairy Products Institute (ADPI) using Beer's law. Standard references of LH and $\mathrm{HH}$ were obtained from the ADPI; these references were used to construct a standard curve to calculate the concentration [transmittance (T\%) vs. WPNI $(\mathrm{mg} / \mathrm{g})$ ] as described in the WPNI method from ADPI (2009). An equation for the standard curve was determined based on the line that best fit the data points $\left(\mathrm{R}^{2}=\right.$ 0.99; Excel 2013, Microsoft Corporation, Redmond, WA):

$$
\mathrm{y}=-5.81 \mathrm{x}+97.9,
$$

where $\mathrm{y}$ is the transmittance (T\%) and $\mathrm{x}$ is the concentration $(\mathrm{mg} / \mathrm{g})$.

\section{Foaming Properties}

Foaming properties (overrun and foam stability) of rehydrated NDM (3.5\% protein (wt/wt)) were examined as reported by Webb et al. (2002) with a few modifications. The overrun was calculated using 100 $\mathrm{mL}$ of dispersion that was poured into a 4.3-L stainless steel bowl and whipped for $15 \mathrm{~min}$ at a speed setting of 10 at $24 \pm 1^{\circ} \mathrm{C}$. The overrun was calculated according to the following equation:

$$
\begin{aligned}
& \% \text { overrun }= \\
& \frac{\text { Mass of liquid dispersion }- \text { Mass of foam }}{\text { Mass of foam }}
\end{aligned}
$$

The foam stability was completed by transferring the foam into a $60-\mathrm{mL}$ soufflé cup (Solo Brand Products Co., Lake Forest, IL) and recording the time in min to account for the $50 \%$ of the initial mass of foam to drain at $24 \pm 1^{\circ} \mathrm{C}$.

\section{Gelling Properties}

For the gelling properties, NDM samples were rehydrated to $3.5 \%$ protein and were acidified with gluconodelta-lactone (GDL; Acros Organics, Springfield Township, NJ) at $2 \%(\mathrm{wt} / \mathrm{vol}$ ) and incubated (model 650D, Fisher Scientific, Pittsburgh, PA) at $37 \pm 1^{\circ} \mathrm{C}$ for $3 \mathrm{~h}$ and placed at $2 \pm 1^{\circ} \mathrm{C}$ for $12 \mathrm{~h}$ according to Bayoumi and Reuter (1989) and Fly et al. (1997). Sodium azide (S227I-1, Fisher Scientific) at 0.1\% (wt/vol) was added 
to the preacidified milk to prevent bacterial growth (Ji et al., 2016). The chemically acidified milk gel was evaluated for WHC according to Parnell-Clunies et al. (1986), gel firmness and cohesiveness according to Lucey (2001), and syneresis according to Amatayakul et al. (2006) with slight modifications. To measure the WHC, $20 \mathrm{~mL}$ of the acidified milk was centrifuged (Fisher Scientific Marathon 21000r) at 13,500 $\times g$ for $30 \mathrm{~min}$ at $4 \pm 1^{\circ} \mathrm{C}$. Gel firmness and cohesiveness were measured using a texture analyzer (model TZ-XT2, Stable Micro System, Surrey, UK), with a 25-mm hemispherical acrylic probe and the calibration was performed using a 300-g weight. The following parameters were selected: test velocity of $2.0 \mathrm{~mm} / \mathrm{s}$ and test distance of $5.0 \mathrm{~mm}$. The Stable Micro System software was used to obtain the values for firmness and cohesiveness.

To measure syneresis, $100-\mathrm{mL}$ sterile specimen containers (Fisher Scientific) were filled with $80 \mathrm{~mL}$ of the acidified milk before incubation and gelling. Gels were stored at $2 \pm 1^{\circ} \mathrm{C}$ for $12 \mathrm{~h}$ and then maintained for $2 \mathrm{~h}$ at an angle of $8^{\circ}$ (due to the fragile nature of the GDLacidified gels). The expelled whey was extracted with a syringe (catalog 14-823-435, Fisher Scientific) within $15 \mathrm{~s}$. The specimen container was weighed empty, with the acidified milk and after the expelled whey was extracted. Syneresis was calculated based on the following equation (Amatayakul et al., 2006):

$$
\text { Syneresis }=\frac{\left(W_{1}-W_{2}\right)}{\left(W_{1}-W_{0}\right)} \times 100,
$$

where $W_{0}$ is the weight $(\mathrm{g})$ of the empty specimen container, $W_{1}$ is the weight $(\mathrm{g})$ of the specimen container + sample, and $W_{2}$ is the weight $(\mathrm{g})$ of the specimen container + sample after whey was extracted.

\section{Emulsion Properties}

Rehydrated NDM samples were analyzed by a turbidimetric technique for emulsifying activity index (EAI) and emulsion stability index (ESI) as described by Pearce and Kinsella (1978). For the EAI, emulsions were prepared with $10 \mathrm{~mL}$ of peanut oil (Hollywood Enriched Gold Peanut Oil, Boulder, CO), using a homogenizer (CAT X120, PolyScience, Niles, IL) at medium speed for $90 \mathrm{~s}$. The absorbance of the diluted emulsions was measured using a spectrophotometer (Genesys5, Thermo Electron Corporation, Madison, WI) at $500 \mathrm{~nm}$ in a $1-\mathrm{cm}$ pathlength cuvette. The oil fraction of the emulsion was calculated by drying 1 $\mathrm{mL}$ of the emulsion and $1 \mathrm{~mL}$ of the rehydrated NDM (model 750F, Fisher Scientific). The densities of the rehydrated NDM were calculated using a pycnometer
$(5 \times 2.5 \mathrm{~cm}$; cat. $03247 \mathrm{Q}$, Fisher Scientific) $)$ at $24 \pm$ $1^{\circ} \mathrm{C}$. After this procedure, the emulsions were stored at $4 \pm 1^{\circ} \mathrm{C}$ for $24 \mathrm{~h}$ and reanalyzed for EAI as previously described to calculate the ESI.

\section{Heat Stability}

The heat stability was defined as the heat coagulation time (HCT) of the rehydrated NDM dispersions following the method from Davis and White (1966) with some modifications. Two milliliters of rehydrated NDM samples was placed in an 8-mL glass vial (Wheaton Clear Glass Sample Vials, Fisher Scientific). The vials were fixed to a metal rocker, which was then immersed in an oil bath maintained at $140 \pm 1^{\circ} \mathrm{C}$. The HCT was recorded as the time elapsed between immersing the samples in the hot oil bath and the beginning of visible clots that suggest coagulation. The HCT was tested for native $\mathrm{pH}$ and adjusted $\mathrm{pH}$ (range from 6.4 to 7.2).

\section{Experimental Design and Statistical Analysis}

Most functionality tests on the NDM samples were done in a rehydrated system. Rehydration was done to a $3.5 \%$ protein (wt/vol), followed by adjustment to $\mathrm{pH}$ 7.0, before assessment of foaming, gelling, and emulsion properties and heat stability. Three measurements were made of each treatment, and the average was reported. All functional testing was completed within $14 \mathrm{~d}$ after the dry heat treatment.

A randomized complete block design was used with replication as block factor. Results were assessed using SAS v.9.4 (SAS Institute Inc., Cary, NC). To determine differences in the functionality, the means of the LH and the dry-heated LH were compared by 1-way ANOVA. Dry-heated NDM was processed on 3 different days, which were regarded as the 3 replications, and significant means at a level of $P \leq 0.05$ were differentiated with Tukey's significant difference test. To compare the functionality of the dry-heated LH against the $\mathrm{HH}$, a 1-way ANOVA was used to compare the dryheated LH means using Dunnett's method to obtain significantly different treatments. Again, significance was determined at a $P \leq 0.05$, blocked by replication $(\mathrm{n}=3)$.

\section{RESULTS AND DISCUSSION}

\section{Compositional Analysis}

Table 1 summarizes the compositional analysis of the $\mathrm{HH}$ and LH. The composition of HH and LH was similar for all components, but LH had greater amounts of protein and moisture whereas the $\mathrm{HH}$ had a greater 


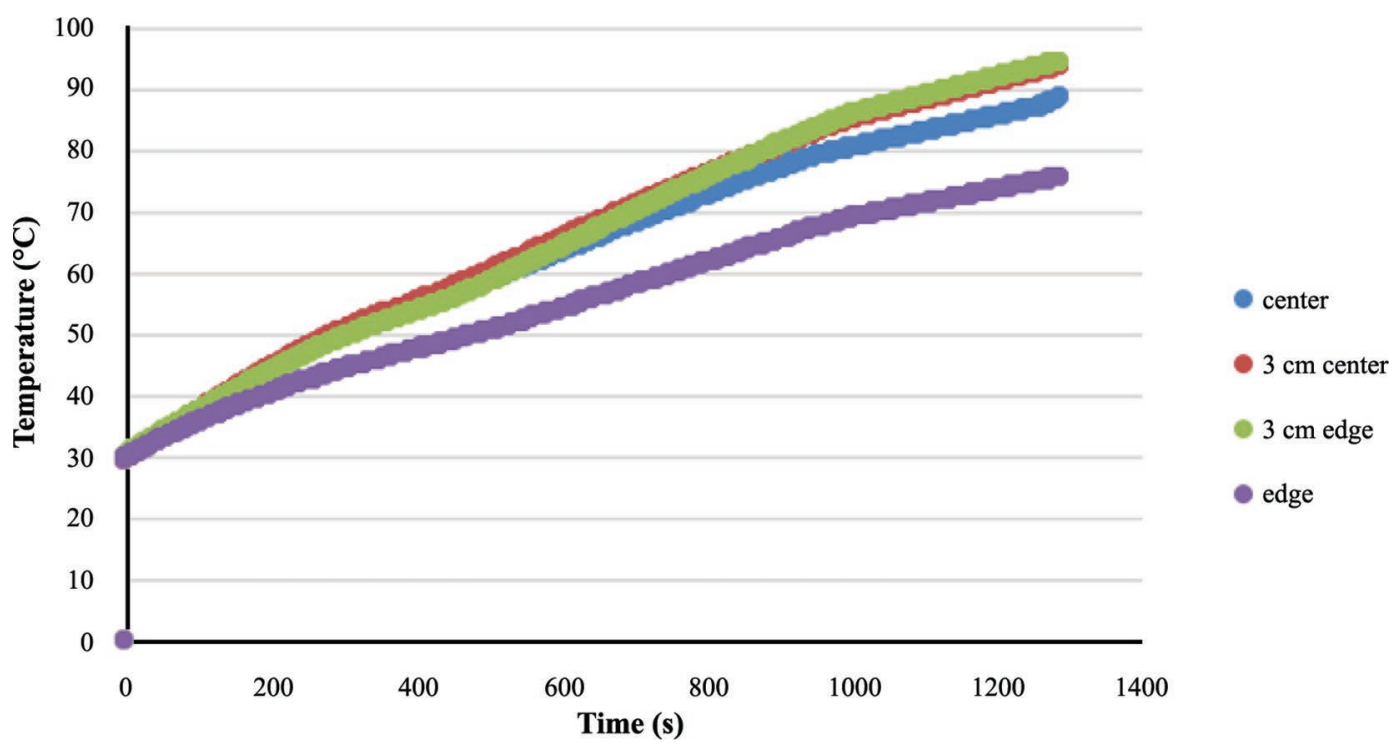

Figure 1. Radio frequency dielectric heating profile [temperature $\left({ }^{\circ} \mathrm{C}\right)$ vs. time $(\mathrm{s})$ ] of low-heat (LH) nonfat dry milk (NDM) in a circular polypropylene tray to $90^{\circ} \mathrm{C}$. The different colors represent the fiber-optic probe locations in the NDM. Center (blue), $3 \mathrm{~cm}$ from the center (red), $3 \mathrm{~cm}$ from the edge (green), and edge (purple).

amount of carbohydrates. The main difference between these 2 powders is reflected by the WPNI results. The WPNI is an analytical method that indicates the amount of native WP resulting from the application of prior heat treatments. This method is critical to classify the NDM into HH or LH (ADPI, 2017). The results from Table 1 are in accordance with this classification. The LH showed a WPNI of 7.26; theoretically, LH has a WPNI value of 6.0 or greater. On the other hand, the $\mathrm{HH}$ showed a WPNI of 1.42 , which is also in accordance with the method, where the WPNI has to be lower than 1.5 to be classified as $\mathrm{HH}$.

\section{RFDH Heating}

One advantage of the RFDH process is its rapid heating (Michael et al., 2014). Times in the RFDH were monitored for all trials and reflect the minutes to increase the temperature of the $\mathrm{LH}$ from $\sim 30^{\circ} \mathrm{C}$ to the target temperature (target temperature was based on the center fiber optic probe, as this probe was typically the last probe to reach the desired temperature of probes, excluding the edge probe. Figure 1 displays the heating profile of a $\mathrm{LH}$ heated to $90^{\circ} \mathrm{C}$ with 3 probes placed at the center, $3 \mathrm{~cm}$ from the center, and $3 \mathrm{~cm}$ from the edge. These 3 probes record a temperature that is fairly consistent, while the edge probe lags. This heating profile was typical in these experiments and the lower temperature was attributed to the edge effect. This was the reason for the removal of $\sim 200 \mathrm{~g}$ of $\mathrm{LH}$ from the center of the tray when exiting the convection oven. Boreddy et al. (2016) also reported a $19^{\circ} \mathrm{C}$ difference in the temperature of the edge and center when heating EWP in the RFDH unit.

The average times in the RFDH unit are shown in Table 2. As can be seen in Table 2, the times to reach the target temperatures of 80,85 , or $90^{\circ} \mathrm{C}$ were very quick and consistent as the average ranged from 16.5 to 20.5 min (all times based on the fiber-optic probe placed in the center of the cylindrical tray). If considering the amount of time to heat NDM from $\sim 30^{\circ} \mathrm{C}$ to one of these target temperatures in a hot-air oven, the time would be substantially greater (data not shown).

\section{Effect of the Dry Heat Treatment on the Functionality of $\mathrm{LH}$}

Table 3 shows the effect of the dry heat treatment on the foaming properties of LH. The foam capacity is

Table 1. Composition analysis of high-heat (HH) and low-heat (LH) nonfat dry milk ${ }^{1}$

\begin{tabular}{lrr}
\hline Component & \multicolumn{1}{c}{ HH } & \multicolumn{1}{c}{ LH } \\
\hline Total protein (\%) & $36.25 \pm 0.02$ & $36.43 \pm 0.15$ \\
Moisture (\%) & $2.45 \pm 0.52$ & $3.62 \pm 0.60$ \\
Fat (\%) & $1.50 \pm 0.10$ & $1.40 \pm 0.00$ \\
Ash (\%) & $7.79 \pm 0.49$ & $7.54 \pm 0.54$ \\
Carbohydrates (\%) & $52.01 \pm 0.95$ & $51.01 \pm 1.17$ \\
WPNI $^{2}$ & $1.42 \pm 0.61$ & $7.26 \pm 0.08$ \\
\hline
\end{tabular}

${ }^{1}$ Mean \pm SD $(\mathrm{n}=3)$.

${ }^{2}$ Whey protein denaturation index. 
Table 2. Heating times for the radio frequency dielectric heating $(\mathrm{RFDH})$ and total heating time of low-heat nonfat dry milk (NDM)

\begin{tabular}{lcc}
\hline $\mathrm{NDM}^{1}$ & $\begin{array}{c}\text { RFDH time } \\
(\mathrm{min})\end{array}$ & $\begin{array}{c}\text { Total heating } \\
\text { time }(\mathrm{min})\end{array}$ \\
\hline $80 / 60$ & $16.50 \pm 1.1$ & 76.50 \\
$80 / 90$ & $17.48 \pm 1.8$ & 107.5 \\
$85 / 60$ & $20.13 \pm 2.3$ & 80.1 \\
$85 / 90$ & $20.00 \pm 1.7$ & 110.0 \\
$90 / 60$ & $20.46 \pm 1.6$ & 80.5 \\
$90 / 90$ & $20.41 \pm 1.4$ & 110.4 \\
\hline
\end{tabular}

${ }^{1}$ Treated in $\mathrm{RFDH}$ unit to 80,85 , or $90^{\circ} \mathrm{C}$ (first number), then placed in a convection oven for 60 or $90 \mathrm{~min}$ (second number).

${ }^{2}$ Mean $\pm \mathrm{SD}(\mathrm{n}=3)$.

defined as the volume of the foam formed under fixed conditions, and the foam stability refers to the ability of the foam to maintain some of its properties with time (Marinova et al., 2009). Statistically LH exhibited a lower overrun and less foam stability compared with all the dry-heated LH $(P<0.05)$. Samples $85 / 60$, $85 / 90,90 / 60$, and $90 / 90$ had $\sim 11,12,14$, and $15 \%$ more overrun and $\sim 14,33,48$, and $49 \%$ more foam stability, respectively, compared with LH. Based on these results, it can be concluded that the dry heat treatment of $\mathrm{LH}$ improved the foaming properties.

Previous research has shown that preheat treatment affects the foaming properties of reconstituted milks (Augustin and Clarke, 2008). This research investigated the following preheat treatments: $72^{\circ} \mathrm{C}$ for $30 \mathrm{~s}$ and $85^{\circ} \mathrm{C}$ for $30 \mathrm{~min}$. The authors reported that foaming properties were greater for the reconstituted milk that was treated at $85^{\circ} \mathrm{C}$. They also reported that this enhanced foaming properties could be attributed to the denatured WP, which increased the ability to hold water (Augustin and Clarke, 2008).

The effect of a dry heat treatment on the foaming properties of NDM has not been described in published literature; however, the effect was reported using EWP
(Boreddy et al., 2016). The foaming properties of RFDH-treated EWP increased with increased temperature and time of the RFDH treatment. They found that a $\mathrm{RFDH}$ treatment of $90^{\circ} \mathrm{C}$ for $24 \mathrm{~h}$ produced maximum foaming capacity (Boreddy et al., 2016). This agrees with these results, where the dry heat treatment seemed to improve the foaming properties of the milk proteins when treated at a temperature of $90^{\circ} \mathrm{C}$ for 60 and $90 \mathrm{~min}$.

The RFDH treatment is considered a dry-heating method and previous research has shown that even minor structural modifications that occur during the dry-heating process can influence the foaming properties of proteins (Desfougères et al., 2008). Desfougères et al. (2008) mentioned one of the advantages of dry heating compared with spray drying is the improvement of foaming properties on hen white egg lysozyme. They showed that dry-heating hen white egg lysozyme at $80^{\circ} \mathrm{C}$ drastically improved the foaming properties of lysozyme at $\mathrm{pH}$ 7.0. The foam density, stability, and drainage rate reached 189,525 , and $7 \%$ of the values obtained for native lysozyme, respectively. Other advantages cited were less solubility loss and more industry applications of this heating method.

Table 3 shows the results for the emulsion properties. The EAI indicates the surface area stabilized by a unit weight of protein, representing a function of oil volume fraction, protein concentration, and type of equipment used to produce the emulsion (Pearce and Kinsella, 1978). The ESI depends on the hydrophobic domains oriented toward the oil phase. For this reason, some level of protein denaturation is ideal because the exposure of its hydrophobic domains affects the emulsion properties (Poon et al., 2001). Some WP denaturation is necessary to obtain an adequate EAI and ESI because surface denaturation exposes the protein sulfhydryl groups promoting disulfide bonding, which is

Table 3. Foam overrun, foam stability (FS), emulsion activity index (EAI), emulsion stability index (ESI), and heat coagulation time $(\mathrm{HCT})$ of low-heat $(\mathrm{LH})$ nonfat dry milk (NDM) and dry-heated NDM ${ }^{1}$

\begin{tabular}{|c|c|c|c|c|c|}
\hline $\mathrm{NDM}^{2}$ & Overrun (\%) & $\mathrm{FS}(\min )$ & EAI $\left(\mathrm{m}^{2} / \mathrm{g}\right)$ & ESI (h) & $\begin{array}{c}\text { HCT (min) } \\
\text { native } \mathrm{pH}\end{array}$ \\
\hline LH & $647.34 \pm 7.38^{\mathrm{c}}$ & $33.30 \pm 1.56^{\mathrm{d}}$ & $275.85 \pm 9.19$ & $59.21 \pm 3.49^{\mathrm{a}}$ & $9.26 \pm 0.08^{\mathrm{b}}$ \\
\hline $80 / 60$ & $683.24 \pm 1.94^{\mathrm{b}}$ & $37.56 \pm 1.43^{\mathrm{cd}}$ & $289.18 \pm 6.78$ & $52.61 \pm 3.33^{\mathrm{ab}}$ & $11.25 \pm 0.43^{\mathrm{b}}$ \\
\hline $80 / 90$ & $688.44 \pm 6.49^{\mathrm{b}}$ & $38.58 \pm 2.15^{\mathrm{c}}$ & $298.44 \pm 39.01$ & $46.08 \pm 5.41^{\mathrm{ab}}$ & $17.91 \pm 1.89^{\mathrm{a}}$ \\
\hline $85 / 60$ & $719.74 \pm 8.73^{\mathrm{a}}$ & $37.93 \pm 0.41^{\mathrm{cd}}$ & $311.35 \pm 10.15$ & $52.77 \pm 1.97^{\mathrm{ab}}$ & $7.43 \pm 0.10^{b}$ \\
\hline $85 / 90$ & $723.77 \pm 3.20^{\mathrm{a}}$ & $44.27 \pm 1.05^{\mathrm{b}}$ & $368.91 \pm 25.83$ & $41.31 \pm 4.39^{\mathrm{b}}$ & $18.51 \pm 0.32^{\mathrm{a}}$ \\
\hline $90 / 60$ & $737.37 \pm 2.19^{\mathrm{a}}$ & $49.16 \pm 1.14^{\mathrm{ab}}$ & $311.62 \pm 14.68$ & $55.53 \pm 1.86^{\mathrm{a}}$ & $9.54 \pm 1.36^{\mathrm{b}}$ \\
\hline $90 / 90$ & $742.07 \pm 1.13^{\mathrm{a}}$ & $49.64 \pm 0.32^{\mathrm{a}}$ & $301.69 \pm 48.51$ & $46.61 \pm 1.22^{\mathrm{ab}}$ & $16.65 \pm 0.42^{\mathrm{a}}$ \\
\hline
\end{tabular}


one of the main mechanisms necessary to stabilize the emulsions (Kim et al., 2002).

Overall, the emulsification properties were not improved as a function of the dry heat treatment. Longer exposure time (90 min) seemed to decrease the ESI in the dry-heated LH. Results from previous studies are contradictory. Some studies showed an improvement in the emulsion properties, whereas others showed a decrease in this functionality (Dissanayake and Vasiljevic, 2009; Raikos, 2010; Lam and Nickerson, 2015). The temperature of pretreatments on the emulsifying properties of whey protein isolates (WPI) was studied by Lam and Nickerson (2015). At pH 7.0, they concluded that the EAI declined from $94.7 \mathrm{~m}^{2} / \mathrm{g}$ at $25^{\circ} \mathrm{C}$ to 87.4 $\mathrm{m}^{2} / \mathrm{g}$ at $55^{\circ} \mathrm{C}$, and to $69.2 \mathrm{~m}^{2} / \mathrm{g}$ at $85^{\circ} \mathrm{C}$. They attributed these changes to a greater surface hydrophobicity caused by protein unravelling during the heat treatment (Lam and Nickerson, 2015). The ESI was slightly lower at $\mathrm{pH} 7.0$ if the WPI was treated at $85^{\circ} \mathrm{C}$. The ESI values declined from $21.3 \mathrm{~min}$ at $25^{\circ} \mathrm{C}$, to $18.3 \mathrm{~min}$ at $55^{\circ} \mathrm{C}$, and to $14.9 \mathrm{~min}$ at $85^{\circ} \mathrm{C}$ possibly due to higher surface hydrophobicity, which promoted droplet flocculation (Lam and Nickerson, 2015).

On the other hand, the EAI of WP significantly increased when treated at $90^{\circ} \mathrm{C}$ for $20 \mathrm{~min}$ (Dissanayake and Vasiljevic, 2009). They attributed the enhanced EAI to the exposure of buried hydrophobic groups after the heat treatment. However, the ESI was similar in treated and nontreated samples (Dissanayake and Vasiljevic, 2009). Additionally, $\mathrm{pH}$ is an important factor to consider when studying the emulsifying properties. For the present study, the emulsion properties were measured at $\mathrm{pH}$ 7.0. As suggested by Dissanayake and Vasiljevic (2009), under neutral $\mathrm{pH}$ conditions the WP have a net negative charge, which imparts greater emulsion stability by retarding coalescence through repulsion. They also mentioned that at $\mathrm{pH} 7.0$, the reactivity of free thiol groups in native WP is greater, which caused unfolding of the protein molecules (Dissanayake and Vasiljevic, 2009).

According to literature, the application of heat treatments in milk (as liquid systems), which contain both WP and caseins, needs to be further studied to explain the mechanism for the emulsion formation and its stabilization (Raikos, 2010). For our samples, which were dry-heated, no significant differences were found among the emulsion properties of the dry-heated LH compared with the LH. However, the EAI of the 85/90 was slightly higher than the other dry-heated LH. Changes in the emulsion formation could be due to the protein denaturation of the dry-heated LH. According to literature, large protein aggregates are formed in WP solutions during heat treatments between 60 and $90^{\circ} \mathrm{C}$ for up to $1,000 \mathrm{~s}$, resulting in aggregates that are unable to efficiently cover the fat droplets in the emulsion, leading to emulsion instability (Raikos, 2010).

Gel properties are presented in Table 4. These results suggest that the rehydrated dry-heated LH produced gels that exhibited improved properties compared with the LH $(P<0.05)$. These gels $(9.6 \% \mathrm{TS})$ reached a $\mathrm{pH}$ between 4.6 to 4.5 in $2.5 \mathrm{~h}$ (the initial $\mathrm{pH}$ ranged from 6.58 to 6.78 ). However, these gels were fragile and soft; this could be due to the rapid acidification rate in contrast to the complex network formed during bacteria fermentation. According to literature, physical properties of milk gels made with GDL differ from the milk-based gels produced with bacteria. The main difference is related to the acidification rate; GDL is rapidly hydrolyzed to gluconic acid, dropping the $\mathrm{pH}$ faster, whereas the $\mathrm{pH}$ decreases slowly with the addition of starter cultures (Fox and McSweeney, 2003).

Water-holding capacity improved for all gels made from the dry-heated LH (between 2.1 to $10.7 \%$ ); however, syneresis was lower in gels made from the $80 / 60$

Table 4. Water-holding capacity (WHC), syneresis, firmness, and cohesiveness of gels made from low-heat (LH) nonfat dry milk (NDM) and dry-heated NDM ${ }^{1}$

\begin{tabular}{lclcc}
\hline $\mathrm{NDM}^{2}$ & WHC $(\%)$ & Syneresis $(\%)$ & Firmness $(\mathrm{g})$ & Cohesiveness $(\%)$ \\
\hline $\mathrm{LH}$ & $11.66 \pm 0.61$ & $1.57 \pm 0.32^{\mathrm{ab}}$ & $64.80 \pm 0.80$ & $95.50 \pm 6.26$ \\
$80 / 60$ & $11.90 \pm 0.21$ & $1.01 \pm 0.34^{\mathrm{b}}$ & $61.00 \pm 4.07$ & $96.18 \pm 5.41$ \\
$80 / 90$ & $12.66 \pm 0.52$ & $0.74 \pm 0.04^{\mathrm{b}}$ & $63.14 \pm 6.83$ & $99.40 \pm 9.12$ \\
$85 / 60$ & $12.37 \pm 0.02$ & $1.53 \pm 0.24^{\mathrm{ab}}$ & $61.12 \pm 4.56$ & $96.57 \pm 5.78$ \\
$85 / 90$ & $12.59 \pm 0.28$ & $1.73 \pm 0.18^{\mathrm{ab}}$ & $65.50 \pm 4.04$ & $98.94 \pm 7.24$ \\
$90 / 60$ & $12.71 \pm 0.59$ & $2.33 \pm 0.40^{\mathrm{a}}$ & $60.99 \pm 6.52$ & $94.76 \pm 11.26$ \\
$90 / 90$ & $12.91 \pm 0.44$ & $1.75 \pm 0.19^{\mathrm{ab}}$ & $62.52 \pm 6.41$ & $100.04 \pm 10.20$ \\
\hline
\end{tabular}

${ }^{\mathrm{a}, \mathrm{b}}$ Values within a column with different superscripts differ $(P<0.05)$.

${ }^{1}$ Mean $\pm \mathrm{SE}(\mathrm{n}=3)$.

${ }^{2}$ Treated in radio frequency dielectric heating (RFDH) unit to 80,85 , or $90^{\circ} \mathrm{C}$ (first number), then placed in a convection oven for 60 or $90 \mathrm{~min}$ (second number). 
and 80/90 rehydrated LH (36 and 53\%, respectively). Firmness and cohesiveness properties were similar across all LH gels.

The use of a RFDH treatment has been investigated in different protein products, for example, EWP, for its effect on gelling quality. The RFDH-treated EWP produced gels that exhibited improved WHC and firmness, even to the extent that the EWP gel properties were equivalent to high gel EWP. Similar to the results found in our study, the RFDH treatment temperature of $90^{\circ} \mathrm{C}$ resulted in the greater WHC gels and were similar to the high gel EWP (Boreddy et al., 2016).

The effect of dry heating on the gel properties of WP has been studied (Foegeding, 2006; Gulzar et al., 2012; Lee and Lucey, 2010; Vasbinder et al., 2003). Commercial WPI was heated at $80^{\circ} \mathrm{C}$ (up to $6 \mathrm{~d}$ ), $100^{\circ} \mathrm{C}$ (up to $24 \mathrm{~h}$ ), and $120^{\circ} \mathrm{C}$ (up to $3 \mathrm{~h}$ ) under controlled $\mathrm{pH}(2.5,4.5$, or 6.5$)$ and water activity $(0.23,0.32$, or 0.52 ). Results showed that the most critical factor that affected the gelling properties was the time. Authors reported the formation of soluble aggregates were, in large part, responsible for the improved gel properties of dry-heated proteins (Gulzar et al., 2012).

In milk, gel formation is complex, as several studies have shown the possible milk protein interactions that occur during this process. During the preparation of yogurt, it is essential to include a heat treatment before acidification so to denature the major WP: $\beta$-LG and $\alpha$-LA (Vasbinder et al., 2003; Foegeding, 2006; Lee and Lucey, 2010). Heating the milk before the gel formation creates a complex mixture of native and denatured WP and casein micelles. The denatured WP can form WP aggregates or can associate with the casein micelles. The heating process also initiates protein unfolding, exposing the reactive groups favoring the intermolecular interactions (Vasbinder et al., 2003; Foegeding, 2006; Lee and Lucey, 2010).

Data for heat stability are shown in Table 3 and Figure 2. At native $\mathrm{pH}$, samples treated for $90 \mathrm{~min}$ presented a significantly greater HCT compared with the LH (Table 3). At adjusted pH (6.4 to 7.2), the heat stability seems to be affected positively by the dry heat treatment. Sample $85 / 90$ had greater stability $(\sim 51 \%$ at $\mathrm{pH} 6.4$ and $\sim 57 \%$ at $\mathrm{pH} 6.6$ ) compared with LH. Literature suggests that $\beta-\mathrm{LG}$ and $\kappa-\mathrm{CN}$ have the greatest impact on the HCT-pH profile. $k$-Casein on the surface of casein micelles could be involved in the formation of disulfide-linked complex with $\beta$-LG (Singh, 2004). At $\mathrm{pH} 6.8$ and 7.0, the increased HCT of some of the dryheated $\mathrm{LH}(80 / 60,80 / 90$, and $85 / 90)$ could be associated with the $\beta-\mathrm{LG} / \kappa-\mathrm{CN}$ complexes that contribute to a higher stability of the casein micelle (Singh, 2004).

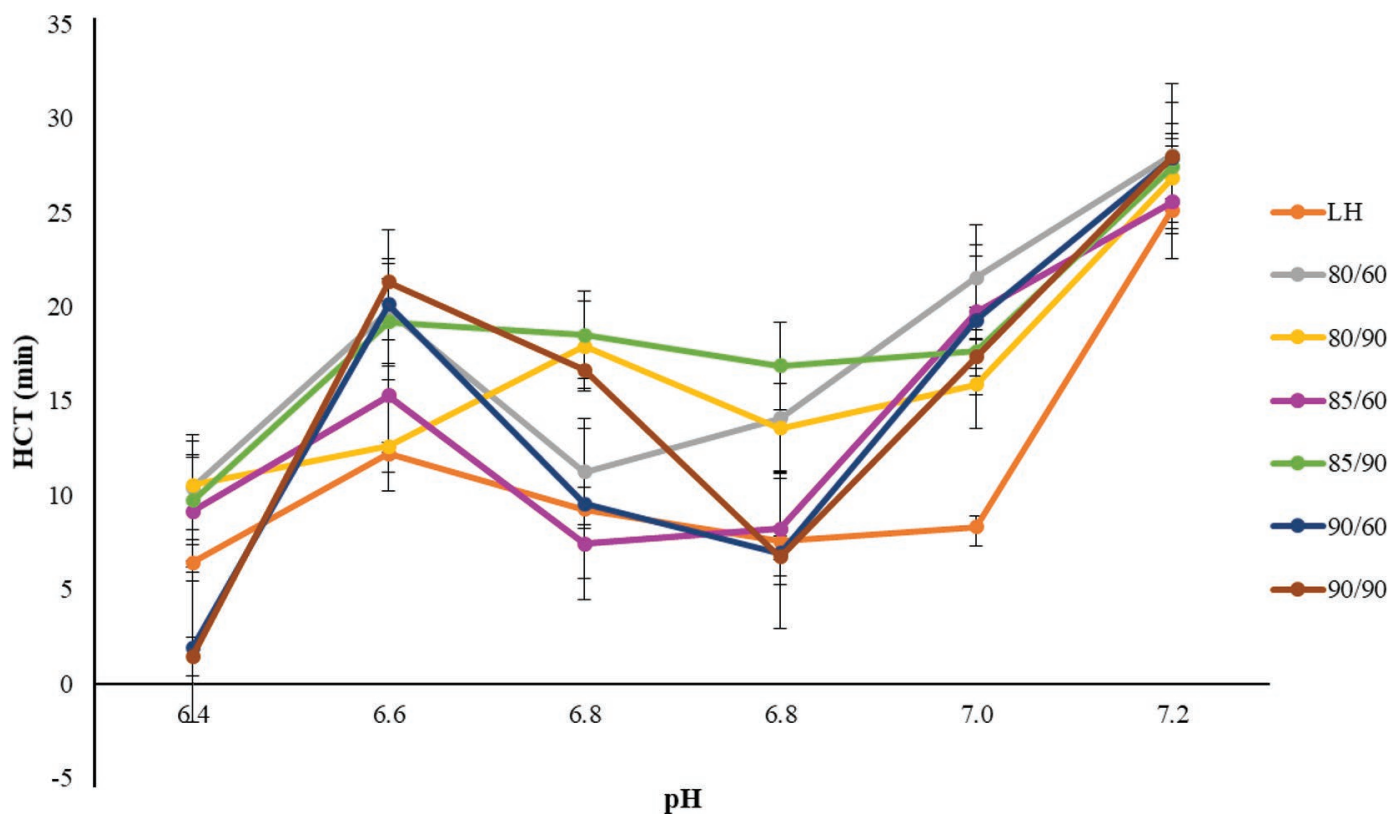

Figure 2. Mean $(\mathrm{n}=3)$ heat coagulation time $(\mathrm{HCT})$ at adjusted $\mathrm{pH}$ of low-heat nonfat dry milk (NDM). LH represents low-heat NDM (orange); the other NDM samples are LH that was heated in a radio frequency dielectric heating (RFDH) unit to a specific temperature, then held at that temperature in a convection oven for a specified time. 80/60 represents heated to $80^{\circ} \mathrm{C}$ and held for 60 min (gray); $80 / 90$ represents heated to $80^{\circ} \mathrm{C}$ and held for $90 \mathrm{~min}$ (yellow); $85 / 60$ represents heated to $85^{\circ} \mathrm{C}$ and held for 60 min (purple); $85 / 90$ represents heated to $85^{\circ} \mathrm{C}$ and held for $90 \mathrm{~min}$ (green); $90 / 60$ represents heated to $90^{\circ} \mathrm{C}$ and held for 60 min (blue); $90 / 90$ represents heated to $90^{\circ} \mathrm{C}$ and held for 90 min (brown). Error bars represent the SE. 
Table 5. Foam overrun, foam stability (FS), emulsion activity index (EAI), emulsion stability index (ESI), and heat coagulation time (HCT) of rehydrated high-heat $(\mathrm{HH})$ nonfat dry milk (NDM) and dry-heated lowheat $(\mathrm{LH}) \mathrm{NDM}^{1}$

\begin{tabular}{|c|c|c|c|c|c|}
\hline $\mathrm{NDM}^{2}$ & Overrun (\%) & $\mathrm{FS}(\min )$ & EAI $\left(\mathrm{m}^{2} / \mathrm{g}\right)$ & ESI (h) & $\begin{array}{l}\mathrm{HCT}(\min ) \\
\text { native } \mathrm{pH}\end{array}$ \\
\hline $\mathrm{HH}$ & $878.60 \pm 4.92$ & $62.02 \pm 1.19$ & $176.86 \pm 7.07$ & $47.58 \pm 3.19$ & $8.22 \pm 0.18$ \\
\hline $80 / 60$ & $683.24 \pm 1.94 *$ & $37.56 \pm 1.43^{*}$ & $289.18 \pm 6.78^{*}$ & $52.61 \pm 3.33$ & $11.25 \pm 0.43$ \\
\hline $80 / 90$ & $688.44 \pm 6.49^{*}$ & $38.58 \pm 2.15^{*}$ & $298.44 \pm 39.01 *$ & $46.08 \pm 5.41$ & $17.91 \pm 1.89^{*}$ \\
\hline $85 / 60$ & $719.74 \pm 8.73^{*}$ & $37.93 \pm 0.41^{*}$ & $311.35 \pm 10.15^{*}$ & $52.77 \pm 1.97$ & $7.43 \pm 0.10$ \\
\hline $85 / 90$ & $723.77 \pm 3.20^{*}$ & $44.27 \pm 1.05^{*}$ & $368.91 \pm 25.83^{*}$ & $41.31 \pm 4.39$ & $18.51 \pm 0.32^{*}$ \\
\hline $90 / 60$ & $737.37 \pm 2.19^{*}$ & $49.16 \pm 1.14^{*}$ & $311.62 \pm 14.68^{*}$ & $55.53 \pm 1.86$ & $9.54 \pm 1.36$ \\
\hline $90 / 90$ & $742.07 \pm 1.13^{*}$ & $49.64 \pm 0.32^{*}$ & $301.69 \pm 48.51^{*}$ & $46.61 \pm 1.22$ & $16.65 \pm 0.42^{*}$ \\
\hline
\end{tabular}

Moreover, at $\mathrm{pH}$ of 6.8 or below, the WP complexes remain associated with the casein micelle. At $\mathrm{pH} 6.4$ literature suggests that some level of WP denaturation could be beneficial to the heat stability (Singh, 2004; Crowley et al., 2014).

Preheating the milk to increase its heat stability is a normal practice in the food industry. These treatments cause heat denaturation of WP and formation of complex aggregates of $\beta-\mathrm{LG}$ and $\kappa-\mathrm{CN}$. It also causes precipitation of calcium phosphate and shifts in ionic composition of milk serum (Singh and Creamer, 1991). These changes could help to explain why the dry heat treatment improved the heat stability in our study.

When considering all functional testing results conducted on LH-NDM, the dry-heated $\mathrm{LH}$ at $85^{\circ} \mathrm{C}$ for 90 min, $90^{\circ} \mathrm{C}$ for $60 \mathrm{~min}$, and $90^{\circ} \mathrm{C}$ for $90 \mathrm{~min}$ exhibited significantly greater foaming properties and heat stability compared with LH. This indicates that the dryheating process, which combined quickly heating LH using the RFDH to a minimum of $85^{\circ} \mathrm{C}$ and holding $\mathrm{LH}$ for a minimum of $90 \mathrm{~min}$ at that temperature, improved some functional properties. Although improvements in gelling and emulsion properties were not attained, it is important to note that these properties were not detrimentally affected by the dry heat treatment. The one exception is the 85/90 LH, which exhibited a significantly lower ESI than did the LH. Perhaps the optimum dry-heating conditions for improvements in emulsification and gelling properties of LH were outside the scope of this study. Thus, it will be interesting to determine if the dry-heated LH can function as HH.

\section{Functionality of the RFDH-Treated Samples Compared with the $\mathrm{HH}$}

Foaming Properties. As expected, foaming properties are greater in HH compared with LH (Dissanayake and Vasiljevic, 2009). This fact has been shown in previous research where WP retentate samples that were heated to at least $55^{\circ} \mathrm{C}$ at $\mathrm{pH} 7.0$ exhibited improved foaming properties. However, the heat treatment must be controlled because at temperatures $\geq 55^{\circ} \mathrm{C}$, protein aggregation can occur, decreasing protein functionality (Dissanayake and Vasiljevic, 2009).

Although the dry heat treatment of LH increased overrun and foam stability, these values were significantly less than the HH (Table $5 ; P<0.05$ ). If comparing $85 / 90,90 / 60$, and $90 / 90$ with the $\mathrm{HH}$, these foams exhibited $\sim 18,16$, and $15 \%$ less overrun and $\sim 29,21$, and $20 \%$ less foam stability, respectively.

Emulsifying Properties. All dry-heated LH exhibited significantly greater EAI than did the HH $(P<$ 0.05 ). Samples $85 / 60$ and $85 / 90$ increased by 43 and $52 \%$, whereas samples $90 / 60$ and $90 / 90$ increased by 43 and $41 \%$, respectively, compared with the HH (Table $5)$. Perhaps the cause of the differences in EAI between the dry-heated $\mathrm{LH}$ and the $\mathrm{HH}$ is the fat droplet size, which increases with heat treatment. If this happened, then this increased size in the HH sample might lead to inefficient coverage of fat droplets, causing emulsion instability (Millqvist-Fureby et al., 2001).

The emulsifying properties of thermally denatured proteins have been studied with other protein products. Voutsinas et al. (1983) conducted research on the emulsifying properties of soy proteins. Their results showed that the EAI of samples heated to $\sim 80$ to $100^{\circ} \mathrm{C}$ were slightly greater than nonheated samples.

Gel Properties. Results for the GDL acidified gels are shown in Table 6. Results showed that the WHC was lower for all the dry-heated LH compared with the $\mathrm{HH}$; however, there was a constant increase in WHC with an increase in RFDH temperature and exposure time if the HH is not considered. Syneresis seemed to follow the opposite trend, with syneresis being greater 
Table 6. Water-holding capacity (WHC), syneresis, firmness, and cohesiveness of gels made with high-heat $(\mathrm{HH})$ nonfat dry milk (NDM) and dry-heated low-heat (LH) $\mathrm{NDM}^{1}$

\begin{tabular}{lcccr}
\hline $\mathrm{NDM}^{2}$ & $\begin{array}{c}\text { WHC } \\
(\%)\end{array}$ & $\begin{array}{c}\text { Syneresis } \\
(\%)\end{array}$ & $\begin{array}{c}\text { Firmness } \\
(\mathrm{g})\end{array}$ & $\begin{array}{c}\text { Cohesiveness } \\
(\%)\end{array}$ \\
\hline $\mathrm{HH}$ & $15.74 \pm 0.62$ & $0.83 \pm 0.10$ & $77.73 \pm 2.22$ & $128.82 \pm 9.17$ \\
$80 / 60$ & $11.90 \pm 0.21^{*}$ & $1.01 \pm 0.34$ & $61.00 \pm 4.07^{*}$ & $96.18 \pm 5.41^{*}$ \\
$80 / 90$ & $12.66 \pm 0.52^{*}$ & $0.74 \pm 0.04$ & $63.14 \pm 6.83^{*}$ & $99.40 \pm 9.12^{*}$ \\
$85 / 60$ & $12.37 \pm 0.02^{*}$ & $1.53 \pm 0.24$ & $61.12 \pm 4.56^{*}$ & $96.57 \pm 5.78^{*}$ \\
$85 / 90$ & $12.59 \pm 0.28^{*}$ & $1.73 \pm 0.18$ & $65.50 \pm 4.04^{*}$ & $98.94 \pm 7.24^{*}$ \\
$90 / 60$ & $12.71 \pm 0.59^{*}$ & $2.33 \pm 0.40^{*}$ & $60.99 \pm 6.52^{*}$ & $94.76 \pm 11.26^{*}$ \\
$90 / 90$ & $12.91 \pm 0.44^{*}$ & $1.75 \pm 0.19$ & $62.52 \pm 6.41^{*}$ & $100.04 \pm 10.20^{*}$
\end{tabular}

${ }^{1}$ Mean $\pm \mathrm{SE}(\mathrm{n}=3)$.

${ }^{2} \mathrm{LH}$ treated in radio frequency dielectric heating unit to 80,85 , or $90^{\circ} \mathrm{C}$ (first number), then placed in a convection oven for 60 or $90 \mathrm{~min}$ (second number).

*Values within a column differ compared with $\mathrm{HH}(P<0.05)$.

in gels made from 90/90. Firmness and cohesiveness were significantly less in the gels made from dry-heated LH compared with the gels made from the HH.

These results could be explained by the denaturation of WP during the heat treatments. According to literature, the extent of denaturation directly affects the firmness and viscosity of acid milk gels (Lee and Lucey, 2010). Another study reported that the properties of yogurt were affected by the heat processing system type and exposure time. The authors concluded that a temperature of $\sim 90$ to $98^{\circ} \mathrm{C}$ and shorter times $(<2 \mathrm{~min})$ resulted in gels with the greatest firmness and apparent viscosity if the milks were processed using the HTST heating system (Parnell-Clunies et al., 1986).

Heat Stability. The heat stability of $\mathrm{HH}$ and dryheated $\mathrm{LH}$ was assessed at native and adjusted $\mathrm{pH}$. Heat stability values for native and adjusted $\mathrm{pH}$ are shown in Table 5 and Figure 3. At native $\mathrm{pH}$ (6.58 to 6.78), all dry-heated LH had greater heat stability than the HH, except for the 85/60 $(P<0.05)$. All the $\mathrm{LH}$ treated for 90 min exhibited significantly greater HCT than the $\mathrm{HH}$.

The HCT at adjusted $\mathrm{pH}$ (from 6.4 to 7.2 ) is shown in Figure 3. At pH 6.4 the dry-heated LH had significantly greater HCT (on average 65\%), except for the 90/60 and 90/90. At pH 6.8, 7.0, and 7.2, all dry-heated LH had greater HCT than the HH. At pH 7.2 all the samples had a greater heat stability compared with the other $\mathrm{pH}$ adjustments, in accordance with a study that revealed that the higher the $\mathrm{pH}$ of the sample (7.2), the greater the heat stability (Vyas and Tong, 2004).

Variations in the results of this study can be attributed to the NDM. A study conducted in 2010 concluded that the heat stability is influenced by the type of $\mathrm{NDM}$, either $\mathrm{LH}, \mathrm{MH}$, or $\mathrm{HH}$, and that a combination of LH and permeate powder can help to ensure a good heat stability (Sikand et al., 2010).

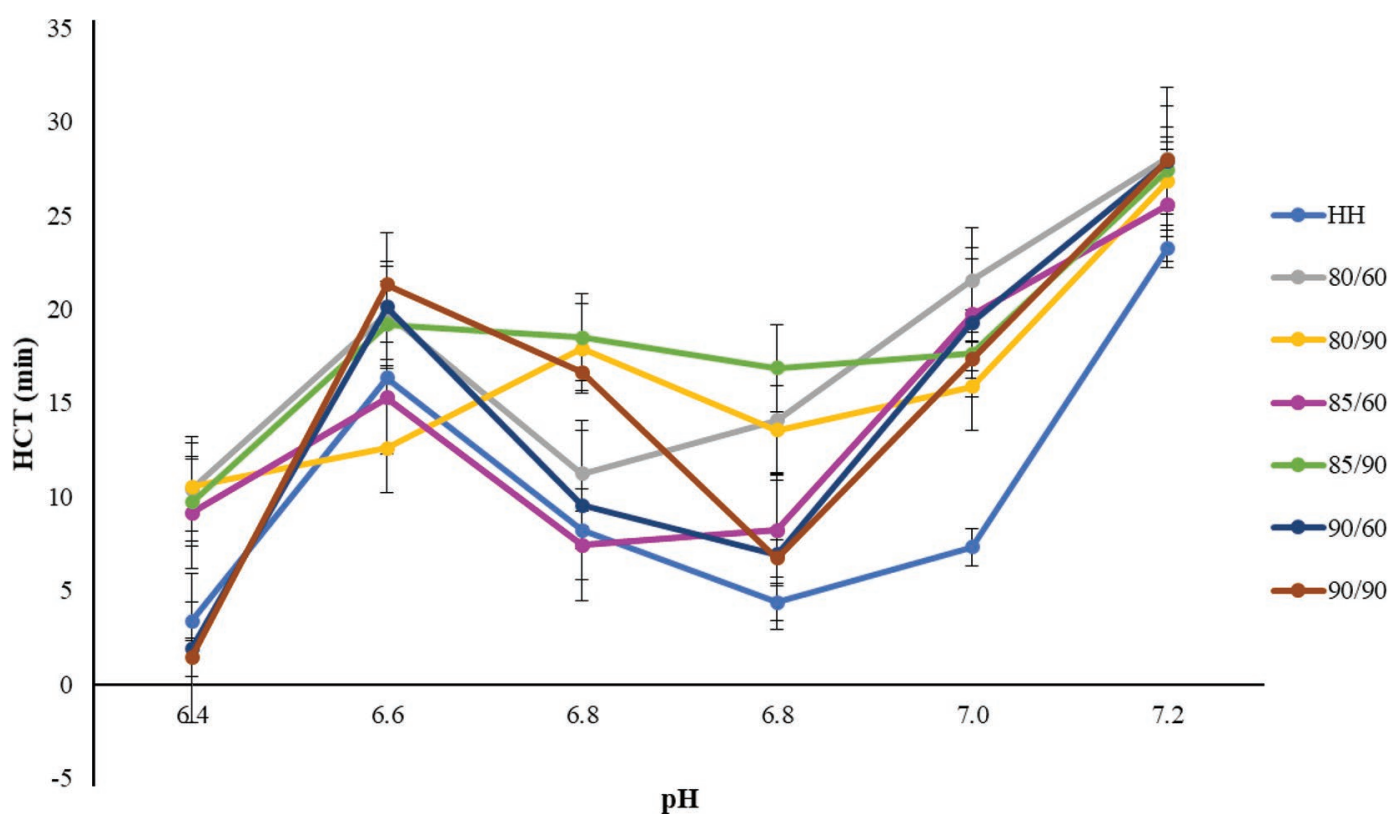

Figure 3. Mean $(\mathrm{n}=3)$ heat coagulation time (HCT) at adjusted $\mathrm{pH}$ of nonfat dry milk (NDM). HH represents high-heat NDM (blue); the other NDM samples are low-heat NDM that was heated in a radio frequency dielectric heating unit to a specific temperature, then held at that temperature in a convection oven for a specified time. 80/60 represents heated to $80^{\circ} \mathrm{C}$ and held for 60 min (gray); $80 / 90$ represents heated to $80^{\circ} \mathrm{C}$ and held for $90 \mathrm{~min}$ (yellow); $85 / 60$ represents heated to $85^{\circ} \mathrm{C}$ and held for 60 min (purple); $85 / 90$ represents heated to $85^{\circ} \mathrm{C}$ and held for $90 \mathrm{~min}$ (green); $90 / 60$ represents heated to $90^{\circ} \mathrm{C}$ and held for $60 \mathrm{~min}$ (darker blue); 90/90 represents heated to $90^{\circ} \mathrm{C}$ and held for 90 min (brown). Error bars represent the SE. 
When considering all functional testing results conducted on dry-heated $\mathrm{LH}$ in comparison to $\mathrm{HH}$, a dry heat treatment of $\mathrm{LH}$ at $80^{\circ} \mathrm{C}$ resulted in improved EAI; however, ESI was not affected. Heat stability was also greater in the dry-heated LH given the treatment time was $90 \mathrm{~min}$. Although improvements in foaming were obtained compared with LH, the dry-heated LH only exhibited about 85 and $80 \%$ of the overrun and foam stability capability in comparison to HH. When considering the foaming and gelling properties as an entity, at most these dry-heated LH seemed to provide a maximum functionality that was only about 0.8 capacity of the HH. Based on these results, we suspect that the quick heating of $\mathrm{LH}$ in the RFDH unit combined with a hold period even 90 min allowed for some WP denaturation, which contributed to the improved functionality of the LH.

Overall, the process of dry-heating LH quickly using the RFDH to at least $85^{\circ} \mathrm{C}$ and holding for at least 90 min improved some functional properties, thus providing evidence that this technology may allow for tailored NDM products that have unique functionality.

\section{CONCLUSIONS}

Dry heat treatments could be used as a process step to improve the functional properties of LH NDM. The dry heat treatment of LH improved the foaming properties and heat stability. Compared with the HH functionality, the dry-heated LH exhibited improved emulsifying and heat stability properties to the extent that they were similar or exceeded the properties of the $\mathrm{HH}$ product. The HH produced superior gels in the terms of firmness and cohesiveness than did the dry-heated LH. The RFDH technology opens the opportunity to develop new ingredients with enhanced characteristics, which can be attributed to the modified functionality of the dry-heated LH. Future work involves extending the hold times to determine if greater improvement of the functional properties of LH could occur as well as to understand the protein denaturation mechanism in a dry system.

\section{ACKNOWLEDGMENTS}

The authors acknowledge the National Dairy Council (Rosemont, IL) and the Kansas State University Research and Experiment Station (Manhattan) for funding part of the research (contribution number 18-495-J from the Kansas Agriculture Experiment Station). The authors also acknowledge the Office of International Affairs and External Cooperation at the University of Costa Rica (San Jose) for the financial support given to the graduate student during the development of this research.

\section{REFERENCES}

American Dairy Products Institute (ADPI). 2009. Standards for Grades of Dry Milk, Including Methods of Analysis. ADPI, Elmhurst, IL.

ADPI. 2017. What does WPNI tell me and how does it compare with other test methods? American Dairy Products Institute, Elmhurst, IL.

Amatayakul, T., F. Sherkat, and N. Shah. 2006. Syneresis in set yogurt as affected by EPS starter cultures and levels of solids. Int. J. Dairy Technol. 59:216-221.

AOAC International. 2002. Official Methods of Analysis. 17th ed. AOAC International, Gaithersburg, MD.

Augustin, M., and P. Clarke. 2008. Skim milk powders with enhanced foaming and steam-frothing properties. Dairy Sci. Technol. 88:149-161.

Bayoumi, S., and H. Reuter. 1989. The use of glucono-delta-lactone in the manufacture of yogurt from UF-milk concentrate. Kieler Milchwirtschaftliche Forschungsberichte 41:159-165.

Boreddy, S. R., H. Thippareddi, G. Froning, and J. Subbiah. 2016. Novel radiofrequency-assisted thermal processing improves the gelling properties of standard egg white powder. J. Food Sci. 81:E665-E671.

Chen, C., M. Michael, R. K. Phebus, H. Thippareddi, J. Subbiah, S. L. Birla, and K. A. Schmidt. 2013. Radio frequency dielectric heating of nonfat radio frequency dielectric heating of nonfat dry milk affects solubility and whey protein nitrogen index. J. Dairy Sci. 96:1471-1476.

Crowley, S. V., M. Megemont, I. Gazi, A. L. Kelly, T. Huppertz, and J. A. O'Mahony. 2014. Heat stability of reconstituted milk protein concentrate powders. Int. Dairy J. 37:104-110.

Davis, D. T., and J. C. D. White. 1966. The stability of milk protein to heat. 1. Subjective measurement of heat stability of milk. J. Dairy Res. 33:67-81.

Desfougères, Y., V. Lechevalier, S. Pezennec, F. Artzner, and F. Nau. 2008. Dry-heating makes hen egg white lysozyme an efficient foaming agent and enables its bulk aggregation. J. Agric. Food Chem. 56:5120-5128.

Dissanayake, M., and T. Vasiljevic. 2009. Functional properties of whey proteins affected by heat treatment and hydrodynamic highpressure shearing. J. Dairy Sci. 92:1387-1397.

Fly, J. A., P. T. Clarke, H. du Parquet, S. Toyne, and M. A. Augustin 1997. Use of glucono-delta-lactone in the manufacture of yogurt. Aust. J. Dairy Technol. 52:20.

Foegeding, E. 2006. Food biophysics of protein gels: A challenge of nano and macroscopic proportions. Food Biophys. 1:41-50.

Fox, P. F., and P. L. H. McSweeney. 2003. Advanced Dairy Chemistry-1 Proteins. 3rd ed. Springer US, Boston, MA.

Gulzar, M., V. Lechevalier, S. Bouhallab, and T. Croguennec. 2012. The physicochemical parameters during dry heating strongly influence the gelling properties of whey proteins. J. Food Eng. 112:296-303.

Gulzar, M., S. Bouhallab, R. Jeantet, P. Schuck, and T. Croguennec. 2011. Influence of $\mathrm{pH}$ on the dry heat-induced denaturation/aggregation of whey proteins. Food Chem. 129:110-116.

Hu, S., Y. Zhao, Z. Hayouka, D. Wang, and S. Jiao. 2018. Inactivation kinetics for Salmonella typhimurium in red pepper powders treated by radio frequency heating. Food Control 85:437-442.

IDF (International Organization for Standardization and International Dairy Federation). 2002. Milk and milk products - Determination of nitrogen content - Routine method using combustion according to the dumas principle (ISO 14891:2002). International Dairy Federation. Brussels, Belgium.

Jeong, S.-G., and D.-H. Kang. 2014. Influence of moisture content on inactivation of Escherichia coli O157:H7 and Salmonella enterica serovar Typhimurium in powdered red and black pepper spices by radio-frequency heating. Int. J. Food Microbiol. 176:15-22. 
Ji, Y., S. K. Lee, and S. G. Anema. 2016. Characterisation of heat-set milk protein gels. Int. Dairy J. 54:10-20.

Kelly, A. L., J. E. O'Connell, and P. F. Fox. 2003. Manufacture and properties of milk powder. P. F. Fox and P. McSweeney, ed. Pages 1027-1054 in Advance Dairy Chemistry, Vol. 1. Proteins. Kluwer Acad/Plenum Publ., New York, NY.

Kim, H., E. A. Decker, and D. J. McClements. 2002. Impact of protein surface denaturation on droplet flocculation in hexadecane oil-inwater emulsions stabilized by beta-lactoglobulin. J. Agric. Food Chem. 50:7131-7137.

Lam, R. S. H., and M. T. Nickerson. 2015. The effect of pH and temperature pre-treatments on the physicochemical and emulsifying properties of whey protein isolate. Food Sci. Technol. 60:427-434.

Lee, W. J., and J. A. Lucey. 2010. Formation and physical properties of yogurt. Asian-Australas. J. Anim. Sci. 23:1127-1136.

Ling, B., J. G. Lyng, and S. Wang. 2018a. Effects of hot air-assisted radio frequency heating on enzyme inactivation, lipid stability and product quality of rice bran. Lebensm. Wiss. Technol. 91:453-459.

Ling, B., J. G. Lyng, and S. Wang. 2018b. Radio-frequency treatment for stabilization of wheat germ: Dielectric properties and heating uniformity. Innov. Food Sci. Emerg. Technol. 48:66-74.

Lucey, J. A. 2001. The relationship between rheological parameters and whey separation in milk gels. Food Hydrocoll. 15:603-608.

Marinova, K. G., E. S. Basheva, B. Nenova, M. Temelska, A. Y. Mirarefi, B. Campbell, and I. B. Ivanov. 2009. Physico-chemical factors controlling the foamability and foam stability of milk proteins: Sodium caseinate and whey protein concentrates. Food Hydrocoll. 23:1864-1876.

Michael, M., R. K. Phebus, H. Thippareddi, J. Subbiah, S. L. Birla, and K. A. Schmidt. 2014. Validation of radio-frequency dielectric heating system for destruction of Cronobacter sakazakii and Salmonella species in nonfat dry milk. J. Dairy Sci. 97:7316-7324.

Millqvist-Fureby, A., U. Elofsson, and B. Bergenstahl. 2001. Surface composition of spray-dried milk protein-stabilised emulsions in relation to pre-heat treatment of proteins. Colloids Surf. B Biointerfaces 21:47-58.

Mulvihill, D. M., and M. Donovan. 1987. Whey proteins and their thermal denaturation - A review. Int. J. Food Sci. Technol. 11:43-75.

Parnell-Clunies, E. M., Y. Kakuda, K. Mullen, D. R. Arnott, and J. M. deMan. 1986. Physical properties of yogurt: A comparison of vat versus continuous heating systems of milk. J. Dairy Sci. 69:2593-2603.
Patel, H., and S. Patel. 2015. Understanding the role of dairy proteins in ingredient and product performance. Dairy Export Council, Arlington, VA.

Pearce, K. N., and J. E. Kinsella. 1978. Emulsifying properties of proteins: Evaluation of a turbidimetric technique. J. Agric. Food Chem. 26:716-723.

Poon, S., A. E. Clarke, and C. J. Schultz. 2001. Effect of denaturants on the emulsifying activity of proteins. J. Agric. Food Chem. 49:281-286.

Raikos, V. 2010. Effect of heat treatment on milk protein functionality at emulsion interfaces. A review. Food Hydrocoll. 24:259-265.

Samarokoon, T. 2016. Fat analysis using microwave radiation (CEM), SMART TracTM Fat and Moisture Analyzer. April. 6, 2016. Kansas State University, Manhattan.

Sanchez Alan, K., L. Wang, and K. Schmidt. 2017. Heat stability of radio frequency dielectric heat treated low heat and high heat nonfat dry milk. Int. Dairy J. 74:21-26.

Sharma, A., A. H. Jana, and R. S. Chavan. 2012. Functionality of milk powders and milk-based powders for end use applications-A review. Compr. Rev. Food Sci. Food Saf. 11:518-528.

Sikand, V., P. S. Tong, and J. Walker. 2010. Heat stability of reconstituted, protein-standardized skim milk powders. J. Dairy Sci. 93:5561-5571.

Singh, H., and L. K. Creamer. 1991. Denaturation, aggregation and heat stability of milk protein during the manufacture of skim milk powder. J. Dairy Res. 58:269-283.

Singh, H. 2004. Heat stability of milk. Int. J. Dairy Technol. 57:111119

Vasbinder, A. J., A. C. Alting, R. W. Visschers, and C. G. de Kruif. 2003. Texture of acid milk gels: Formation of disulfide cross-links during acidification. Int. Dairy J. 13:29-38.

Voutsinas, L., E. Cheung, and S. Nakai. 1983. Relationships of hydrophobicity to emulsifying properties of heat denatured proteins. J. Food Sci. 48:26-32

Vyas, H. K., and P. S. Tong. 2004. Impact of source and level of calcium fortification on the heat stability of reconstituted skim milk powder. J. Dairy Sci. 87:1177-1180.

Webb, M. F., H. A. Naeem, and K. A. Schmidt. 2002. Food protein functionality in a liquid system: A comparison of deamidated wheat protein with dairy and soy proteins. J. Food Sci. 67:28962902 . 